\title{
Ordered mesoporous manganese oxide as catalyst for hydrogen peroxide oxidation of norfloxacin in water
}

\author{
SUI Minghao*, SHE Lei, SHENG Li, WEI Jinjie, ZHANG Lingdian, HUANG Shuhang \\ State Key Laboratory of Pollution Control and Resource Reuse, School of Environmental Science and Engineering, Tongji University, Shanghai 200092, China
}

\section{A R T I C L E I N F O}

\section{Article history:}

Received 31 August 2012

Accepted 22 November 2012

Published 20 March 2013

\section{Keywords:}

Ordered mesoporous material

Manganese oxide

Hydrogen peroxide

Oxidation

Norfloxacin

\begin{abstract}
A B S T R A C T
Ordered mesoporous manganese oxide $\left(\mathrm{om}-\mathrm{MnO}_{x}\right)$ was prepared and used in oxidation by hydrogen peroxide of norfloxacin (NFX). The om- $\mathrm{MnO}_{x}$ was prepared using a hard template method. The catalytic activity of om- $\mathrm{MnO}_{x}$ was investigated by evaluating the changes in degradation efficiency and antibacterial activity of NFX. om- $\mathrm{MnO}_{x}$ exhibited significant catalytic activity for the degradation of NFX in water by hydrogen peroxide. Lower $\mathrm{pH}$ conditions favored the catalytic activity of om- $\mathrm{MnO}_{x} /$ hydrogen peroxide. The presence of om- $\mathrm{MnO}_{x}$ achieved a greater reduction in the antibacterial ability of NFX than that was obtained with hydrogen peroxide alone. The inhibiting effect of $t$-butanol indicated that om- $\mathrm{MnO}_{x}$ enhanced the generation of hydroxyl radicals. Byproducts from $\mathrm{NFX}$ were detected during the om- $\mathrm{MnO}_{x}$-catalyzed hydrogen peroxide process, and possible reaction pathways were proposed.
\end{abstract}

(C) 2013, Dalian Institute of Chemical Physics, Chinese Academy of Sciences. Published by Elsevier B.V. All rights reserved.

\section{Introduction}

Awareness of antibiotics in the environment has increased in the last decade. Most antibiotics are incompletely metabolized during therapy [1]. Norfloxacin (NFX) is one of the quinolones that are among the most important classes of synthetic antibacterial agents, and it is widely used in human and veterinary medicine [2]. It is difficult to biodegrade NFX in aqueous solutions, and chemical oxidation has been considered [3].

Hydrogen peroxide is a very attractive oxidant for the remediation of wastewater containing organic substances. It is cheap, environmentally clean, and easy to handle. However, hydrogen peroxide is a moderately strong oxidant, and poorly active without a catalyst. In recent years, heterogeneous catalytic hydrogen peroxide has been developed, which can partly overcome the drawbacks of the homogenous Fenton system $\left(\mathrm{Fe}^{2+} / \mathrm{H}_{2} \mathrm{O}_{2}\right)$, such as disposing of the Fe-containing waste sludge and the irreversible loss of activity of the reagent. Manganese oxides $\left(\mathrm{MnO}_{x}\right)$ have been found to be active for the decomposition of hydrogen peroxide in aqueous solutions by enhancing the generation of hydroxyl radicals (HO·) [4-6]. Manganese oxide catalysts are often loaded on porous materials (e.g., GAC, SBA-15, and mesoporous $\mathrm{Al}_{2} \mathrm{O}_{3}[5,7,8]$ ) because a higher specific surface area and porous structure favor catalytic activity. However, the unavoidable leaching of Mn from the surface of the support may cause a deterioration in its catalytic activity.

In the present study, manganese oxide with an ordered mesoporous structure $\left(\mathrm{om}-\mathrm{MnO}_{x}\right)$ was prepared and introduced into a hydrogen peroxide oxidation process. Ordered mesoporous materials have attracted growing attention in the last two decades, and they have great potential for applications in environmental remediation as catalyst supports and adsorbents [9]. However, few studies have focused on the catalytic

\footnotetext{
* Corresponding author. Tel: +86-21-65982691; Fax: +86-21-65986313; E-mail: suiminghao.sui@gmail.com

This work was supported by the National Natural Science Foundation of China (50708067, 51078281, 51278351), Foundation for the Author of National Excellent Doctoral Dissertation of China (2007B48), the National Science and Technology Major Project (2012ZX07408001), and the Fundamental Research Funds for the Central Universities (0400219192).
}

DOI: 10.1016/S1872-2067(11)60492-0 | http://www.sciencedirect.com/science/journal/18722067 | Chin. J. Catal., Vol. 34 , No. 3, March 2013 
performances of ordered mesoporous transition-metal oxides. To the best of the authors' knowledge, the catalytic activity of manganese oxide with an ordered mesoporous structure and hydrogen peroxide for the degradation of organic pollutants in water has not been investigated. It is expected that an ordered mesoporous structure and a specific surface area of up to 85.67 $\mathrm{m}^{2} / \mathrm{g}$ would provide favorable manganese oxide catalytic performances in the degradation of NFX by hydrogen peroxide.

\section{Experimental}

\subsection{Catalyst preparation}

The ordered mesoporous $\mathrm{MnO}_{x}$ was prepared by a hard template method using SBA-15 as the hard template and $\mathrm{Mn}\left(\mathrm{NO}_{3}\right)_{2}$ as the $\mathrm{Mn}$ source [10]. The calcination conditions were varied and were found to be an important factor in the ordered structure of $\mathrm{MnO}_{x}$. SBA-15 was prepared using a non-ionic triblock copolymer (P123) as a surfactant and tetraethoxysilane as the silica source [11]. SBA-15 powder was impregnated with $\mathrm{Mn}\left(\mathrm{NO}_{3}\right)_{2}$ solution under stirring. The composite was dried in air at $100{ }^{\circ} \mathrm{C}$ for $12 \mathrm{~h}$. The resulting solid was heated at a rate of $1{ }^{\circ} \mathrm{C} / \mathrm{min}$ and calcined at 150, 200, 250, and $300{ }^{\circ} \mathrm{C}$ for $2 \mathrm{~h}$ and $350{ }^{\circ} \mathrm{C}$ for $5 \mathrm{~h}$. The silica template was removed using a $2 \mathrm{~mol} / \mathrm{L} \mathrm{NaOH}$ solution. As a reference, manganese oxide without an ordered mesoporous structure, designated no- $\mathrm{MnO}_{x}$, was prepared by $\mathrm{Mn}\left(\mathrm{NO}_{3}\right)_{2}$ decomposition and the same calcination conditions as those used in the preparation of om- $\mathrm{MnO}_{x}$.

\subsection{Catalyst characterization}

Transmission electron microscopy (TEM) images of the samples were obtained using a JEM2011 instrument (JEOL, Japan). The sample purities were determined by X-ray fluorescence (XRF) using a Bruker-AXS S4 Explorer instrument. Powder X-ray diffraction (XRD) patterns were recorded on a Rigaku D/max-RB diffractometer with $\mathrm{Cu} K_{\alpha}$ radiation. Nitrogen absorption-desorption isotherms were obtained using a Micromeritics ASAP 2010 apparatus. The multipoint Brunauer-Emmett-Teller method was used to measure the specific surface area, and the pore size distribution was calculated using the Barrett-Joyner-Halenda method. The average oxidation state of $\mathrm{Mn}$ in the samples was measured by potentiometric titration [12].

\subsection{Oxidation experiments}

Experiments were carried out in a glass batch-reactor with continuous stirring. The reaction was initiated by adding catalyst to a solution containing NFX and hydrogen peroxide. Samples were withdrawn at intervals and then filtered through a $0.22 \mu \mathrm{m}$ one-off poly(ether sulphone) syringe filter. Methanol was used to quench any additional oxidation reactions involving residual $\mathrm{H}_{2} \mathrm{O}_{2}$. The $\mathrm{pH}$ of the reaction solution was adjusted using $0.1 \mathrm{~mol} / \mathrm{L} \mathrm{NaOH}$ and $\mathrm{HCl}$, but was not buffered, to avoid the effects of the buffer salt on the catalyst's properties $[13,14]$.
NFX was analyzed at $275 \mathrm{~nm}$ using an ultra-high-performance liquid-chromatography system (ACQUITY UPLC $\mathrm{H}$-Class) and a $100 \mathrm{~mm} \times 2.1 \mathrm{~mm} \mathrm{\textrm {C } _ { 1 8 }} 1.7-\mu \mathrm{m}$ reversed-phase column (ACQUITY UPLC BEH) with $0.1 \%$ formic acid and acetonitrile $(85: 15, \mathrm{v} / \mathrm{v})$ as the mobile phase. Mass spectrometric (MS) analysis ( $m / z: 100-450)$ was performed using a TSQ Quantum (Thermo Fisher Scientific) spectrometer equipped with an electrospray ionization source [15]. The titanium sulfate method was used to analyze the concentration of $\mathrm{H}_{2} \mathrm{O}_{2}$ [16]. The antibacterial activity of NFX was evaluated using the method proposed by Dodd et al. $[17,18]$, and a phosphate buffer of pH 7.0 was used for serial dilution. Mn ions were determined using an Optima 2100 DV ICP spectrometer (PerkinElmer, USA).

\section{Results and discussion}

\subsection{Catalyst characterization results}

The XRD patterns are shown in Fig. 1. Three well-resolved reflections, indexed to (100), (110), and (200), were observed for SBA-15, which suggested that the SBA-15 synthesized in this study possesses a highly ordered hexagonal mesostructure [19]. The positions of the (100) and (110) peaks of om- $\mathrm{MnO}_{x}$ shifted to a lower $d$ spacing. The peak intensities decreased and the (200) peak almost disappeared, which is a result of the incomplete ordered framework of the om- $\mathrm{MnO}_{x}$ sample [20]. The no- $\mathrm{MnO}_{x}$ sample did not show any peaks in the $2 \theta$ range $0^{\circ}-6^{\circ}$ (data not shown here).

The TEM image of SBA-15 suggested a highly ordered porous structure (Fig. 2(a)). From Fig. 2(b), it was clear that om- $\mathrm{MnO}_{x}$ copied the template tunnels. However, the pore diameter of om- $\mathrm{MnO}_{x}$ was smaller than the wall thickness of SBA-15. This may be caused by excessive grain growth of transition-metal oxides in the calcination process. No ordered pore structure was observed for no- $\mathrm{MnO}_{x}$.

Some of the important physicochemical properties of om- $\mathrm{MnO}_{x}$ are listed in Table 1 . The specific surface area of om- $\mathrm{MnO}_{x}\left(85.67 \mathrm{~m}^{2} / \mathrm{g}\right)$ was higher than that of no- $\mathrm{MnO}_{x}$. The TEM image in Fig. 2(d) shows that no- $\mathrm{MnO}_{x}$ has almost no pores. The average pore size of om- $\mathrm{MnO}_{x}(13.2 \mathrm{~nm})$ is in the

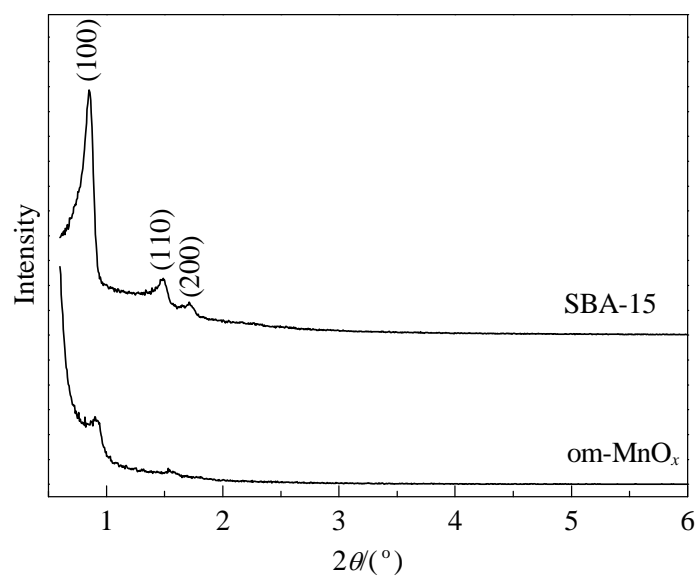

Fig. 1. XRD patterns of $\mathrm{SBA}-15$ and om-MnO ${ }_{x}$. 

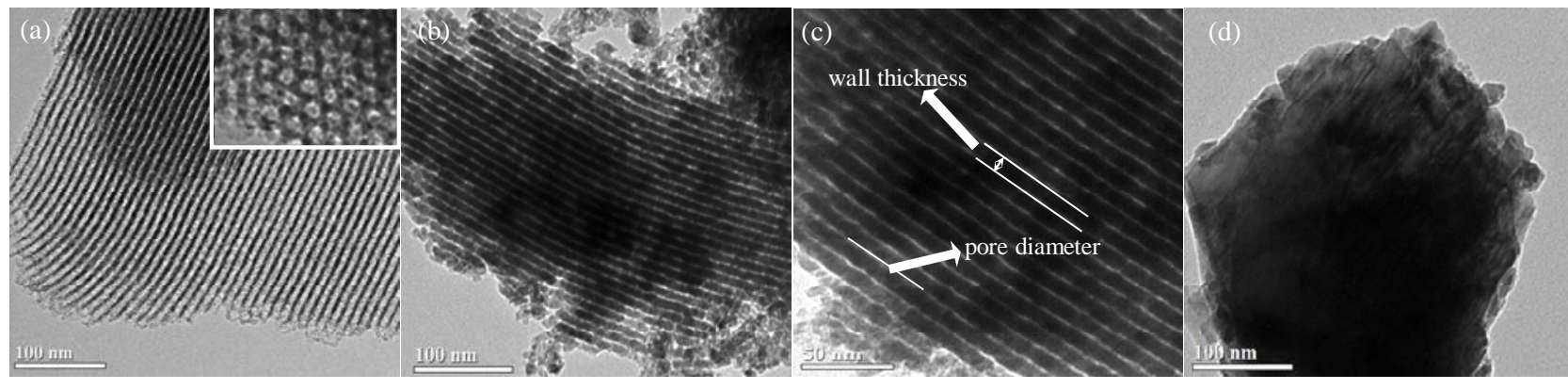

Fig. 2. TEM images of SBA-15 (a), om- $\mathrm{MnO}_{x}(\mathrm{~b}, \mathrm{c})$, and $\mathrm{no}-\mathrm{MnO}_{x}(\mathrm{~d})$.

Table 1

Physicochemical properties of different samples.

\begin{tabular}{lccccc}
\hline Sample & $\begin{array}{c}\mathrm{MnO}_{x} \\
\text { content } \\
(\mathrm{wt} \%)\end{array}$ & $\begin{array}{c}\text { Surface } \\
\text { area } \\
\left(\mathrm{m}^{2} / \mathrm{g}\right)\end{array}$ & $\begin{array}{c}\text { Pore } \\
\text { volume } \\
\left(\mathrm{cm}^{3} / \mathrm{g}\right)\end{array}$ & $\begin{array}{c}\text { Average } \\
\text { pore size } \\
(\mathrm{nm})\end{array}$ & $\begin{array}{c}\text { Average } \\
\text { oxidation } \\
\text { state }\end{array}$ \\
\hline $\mathrm{om}^{-\mathrm{MnO}_{x}}$ & 99.2 & 85.67 & 0.28 & 13.2 & 3.67 \\
${\text { no- } \mathrm{MnO}_{x}}^{9}$ & 97.4 & 0.90 & 0.0076 & - & 3.83 \\
\hline
\end{tabular}

mesoporous range. The average oxidation state of manganese oxide showed that there were more $\mathrm{Mn}^{4+}$ species in no- $\mathrm{MnO}_{x}$ than in om- $\mathrm{MnO}_{x}$.

\subsection{Performance of om- $\mathrm{MnO}_{x}$ as catalysts in hydrogen peroxide} oxidation of NFX

As shown in Fig. 3, under the $\mathrm{pH}$ conditions investigated in these experiments ( $\mathrm{pH} 3.0,7.1$, and 8.7), $\mathrm{H}_{2} \mathrm{O}_{2}$ alone cannot effectively degrade NFX. However, a higher efficiency of NFX degradation was observed in the presence of $\mathrm{MnO}_{x}$. It is obvious that the catalytic activity of om- $\mathrm{MnO}_{x}$ in NFX degradation with $\mathrm{H}_{2} \mathrm{O}_{2}$ is greater than that of no- $\mathrm{MnO}_{x}$. Although om- $\mathrm{MnO}_{x}$ and no- $\mathrm{MnO}_{x}$ both improved the oxidizing ability of $\mathrm{H}_{2} \mathrm{O}_{2}$, a higher NFX degradation efficiency was observed in the catalytic hydrogen peroxide process using om- $\mathrm{MnO}_{x}$. Lower $\mathrm{pH}$ condi- tions were also found to favor the catalytic activity of om- $\mathrm{MnO}_{x} / \mathrm{H}_{2} \mathrm{O}_{2}$. At $\mathrm{pH} 3.0,58.7 \%$ of NFX was degraded in the presence of $1.0 \mathrm{~g} / \mathrm{L}$ of om- $\mathrm{MnO}_{x}$. This was $53.5 \%$ higher than the degradation percentage obtained using $\mathrm{H}_{2} \mathrm{O}_{2}$ alone $(5.2 \%)$. Although the degradation efficiency of NFX decreased with increasing $\mathrm{pH}, 31.3 \%$ of NFX was still degraded at $\mathrm{pH}$ 8.7. It is worth noting that the adsorption of NFX on om- $\mathrm{MnO}_{x}$ accounted for $44 \%-68 \%$ of the total removal efficiency for NFX at the three $\mathrm{pH}$ values, indicating that adsorption of $\mathrm{NFX}$ on om- $\mathrm{MnO}_{x}$ plays an important role in NFX removal. The catalytic activity of om- $\mathrm{MnO}_{x} / \mathrm{H}_{2} \mathrm{O}_{2}$ is evident from a comparison of the NFX catalytic degradation efficiency in om- $\mathrm{MnO}_{x} / \mathrm{H}_{2} \mathrm{O}_{2}$ with the cumulative degradation efficiency of NFX by $\mathrm{H}_{2} \mathrm{O}_{2}$ alone, and adsorption of NFX on om- $\mathrm{MnO}_{x}$.

The deactivation potency with respect to the biological activity must be considered in assessing the oxidation ability when treating antibacterial agents. Deactivation is sufficient for antibacterial agents. Complete removal of the agent from the water is unnecessary and uneconomical. Changes in the antibacterial activities of NFX in $\mathrm{H}_{2} \mathrm{O}_{2}$ oxidation with and without om- $\mathrm{MnO}_{x}$ were investigated. Figure 4 shows the growth inhibition curves. The percentage growth inhibition $I$ of a reference bacterium (Eq. (1)) was plotted against the log of the corresponding sample dilution. Hydrogen peroxide alone and in the

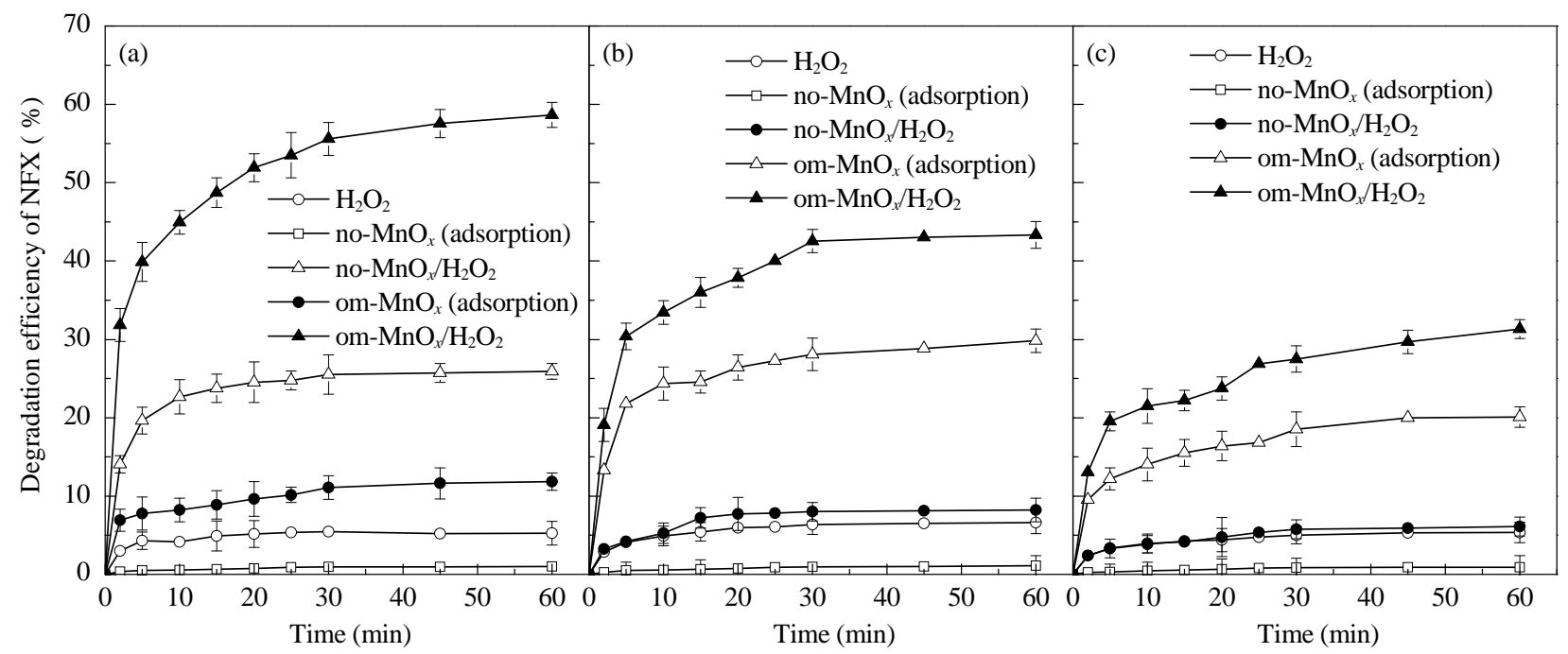

Fig. 3. Catalytic activity of om- $\mathrm{MnO}_{x}$ on hydrogen peroxide for degradation of $\mathrm{NFX}$ at $\mathrm{pH} 3.0$ (a), 7.1 (b), and 8.7 (c). Initial concentration of $\mathrm{H}_{2} \mathrm{O}_{2} 20$ $\mathrm{mmol} / \mathrm{L}$, dose of om- $\mathrm{MnO}_{x}$ and $\mathrm{no}-\mathrm{MnO}_{x} 1.0 \mathrm{~g} / \mathrm{L}$, initial concentration of $\mathrm{NFX} 78 \mu \mathrm{mol} / \mathrm{L}$, temperature $20^{\circ} \mathrm{C}$. 


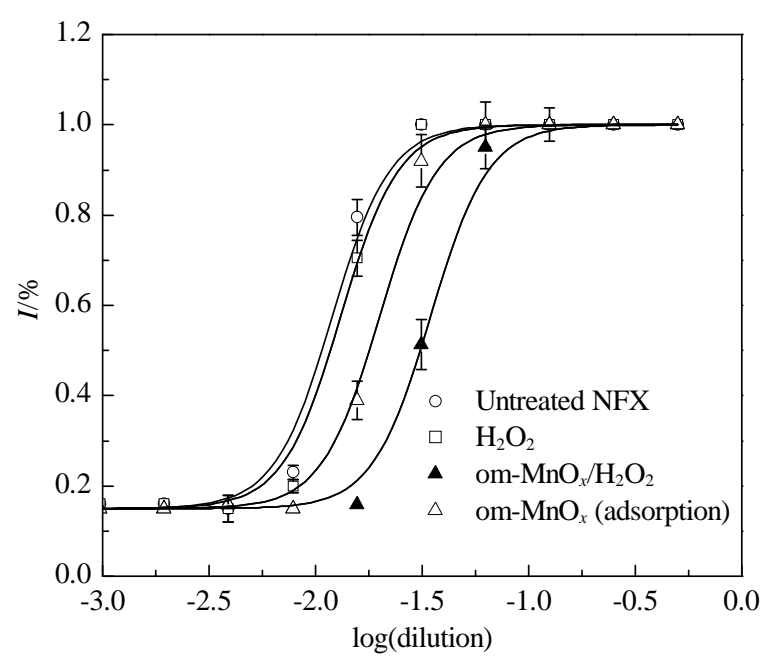

Fig. 4. Dose-response relationship for deactivation of NFX in om- $\mathrm{MnO}_{x}$ catalytic hydrogen peroxide. Initial concentration of $\mathrm{H}_{2} \mathrm{O}_{2} 20$ $\mathrm{mmol} / \mathrm{L}$, oxidation/adsorption time $60 \mathrm{~min}$, dose of om- $\mathrm{MnO}_{x} 1.0 \mathrm{~g} / \mathrm{L}$, initial concentration of NFX $78 \mu \mathrm{mol} / \mathrm{L}$, initial $\mathrm{pH}$ of 3.0, temperature $20^{\circ} \mathrm{C}$.

presence of om- $\mathrm{MnO}_{x}$ both caused a shift to the right relative to the curve corresponding to the untreated NFX sample in the corresponding dose-response curves, indicating that the antibacterial activity of NFX was reduced. However, it is obvious that the presence of om- $\mathrm{MnO}_{x}$ reduced the antibacterial ability of NFX to a greater extent than $\mathrm{H}_{2} \mathrm{O}_{2}$ alone did. The adsorption of $\mathrm{NFX}$ on om- $\mathrm{MnO}_{x}$ caused some of the reduction in the antibacterial activity of NFX.

$$
I(\%)=\frac{\left(A_{\max }-A\right)}{\left(A_{\max }-A_{\min }\right)} \times 100
$$

where $A_{\min }$ and $A_{\max }$ are $100 \%$ and $0 \%$ growth inhibitions, which correspond to negative and positive growth controls, respectively, and $A$ is the adsorption of each sample at $625 \mathrm{~nm}$.

\subsection{Preliminary considerations of reaction mechanism}

\subsubsection{Effect of t-butanol on om- $\mathrm{MnO}_{x} /$ hydrogen peroxide catalytic process}

It has been suggested that the catalytic ability of $\mathrm{Mn} /$ hydrogen peroxide in aqueous solutions is the result of promotion of the generation of hydroxyl radicals in homogeneous or heterogeneous catalytic systems [5]. Hydroxyl radicals react non-selectively with organic matter in aqueous solutions at a rate of $10^{3}-10^{11} \mathrm{~mol} /(\mathrm{L} \cdot \mathrm{s})$ [21]. $t$-Butanol (TBA), a hydroxyl radical scavenger, was used to investigate whether hydroxyl radical generation was promoted in the presence of om- $\mathrm{MnO}_{x}$. TBA has a relatively fast reaction rate with hydroxyl radicals $\left[6 \times 10^{8} \mathrm{~mol} /(\mathrm{L} \cdot \mathrm{s})\right]$ [22], and the presence of TBA quenches the hydroxyl radical chain reaction by producing inert intermediates, resulting in a decrease in the oxidation of target compounds. The effect of TBA on the degradation efficiency of NFX is shown in Fig. 5. In oxidation with $\mathrm{H}_{2} \mathrm{O}_{2}$ alone, $1.5 \%$ and $2.6 \%$ reductions in the degradation efficiency of NFX were observed in the presence of 50 and $100 \mathrm{mg} / \mathrm{L}$, respectively, of TBA. It was found that the presence of 50 and 100

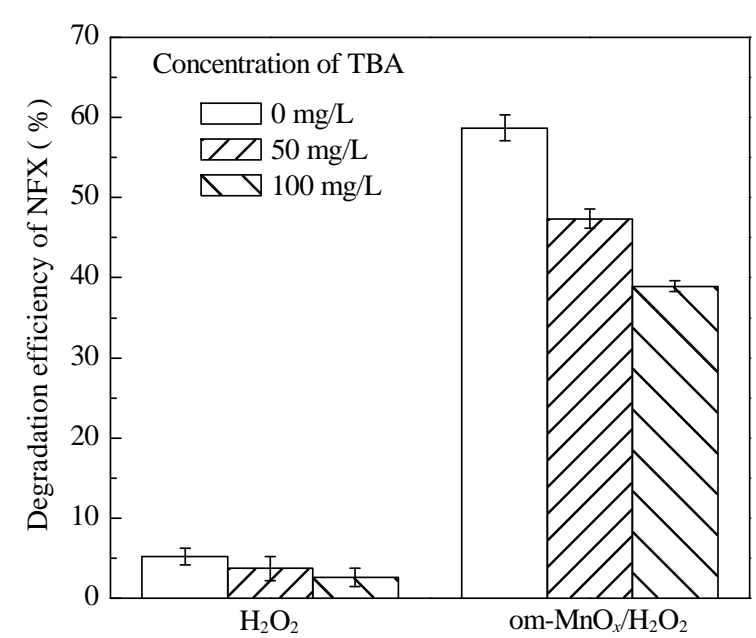

Fig. 5. Effect of tert-butanol on om- $\mathrm{MnO}_{x}$ catalytic hydrogen peroxide. Initial concentration of $\mathrm{H}_{2} \mathrm{O}_{2} 20 \mathrm{mmol} / \mathrm{L}$, dose of om- $\mathrm{MnO}_{x} 1.0 \mathrm{~g} / \mathrm{L}$, initial concentration of NFX $78 \mu \mathrm{mol} / \mathrm{L}$, initial $\mathrm{pH}$ of 3.0, and temperature $20^{\circ} \mathrm{C}$.

$\mathrm{mg} / \mathrm{L}$ of TBA had a significant impact on NFX degradation, and the degradation efficiencies decreased by $11.7 \%$ and $19.6 \%$, respectively, indicating that $\mathrm{om}-\mathrm{MnO}_{x}$ enhanced the generation of hydroxyl radicals. The generated hydroxyl radicals then reacted with NFX adsorbed on the om- $\mathrm{MnO}_{x}$ surface and/or diffused into the aqueous solution to oxidize NFX.

\subsubsection{Degradation intermediates and destruction pathways for NFX}

The byproducts of NFX oxidation in the system with om- $\mathrm{MnO}_{x} / \mathrm{H}_{2} \mathrm{O}_{2}$ at pH 3.0 were identified. MS analysis of NFX showed several fragmentation products, and an MS fragmentation pattern was proposed. The MS data are summarized in Table 2. The detailed degradation pathways are illustrated in Scheme 1. Based on the fragmentation products, the oxidation processes primarily occurred in the piperazine ring and nalidixic ring of NFX, indicating that hydroxyl radicals were involved in the catalytic reaction $[15,23]$. Three possible pathways for reactions between NFX and hydroxyl radicals are proposed. (1) Pathway I: oxidation at the nalidixic ring. First, hydroxyl radicals oxidize the carboxyl group in the nalidixic ring. Hydroxyl radicals then attack the double bond in the na-

\section{Table 2}

Summary of fragmentation products from NFX catalytic oxidation.

\begin{tabular}{ccccc}
\hline No. & $\begin{array}{c}{[\mathrm{M}+\mathrm{H}]^{+}} \\
\text {measured }\end{array}$ & $\begin{array}{c}\text { Nominal } \\
\text { mass }\end{array}$ & $\begin{array}{c}\text { Molecular } \\
\text { formula }\end{array}$ & $\begin{array}{c}\text { Chemical } \\
\text { structure }\end{array}$ \\
\hline NFX & 320 & 319 & $\mathrm{C}_{16} \mathrm{H}_{18} \mathrm{FN}_{3} \mathrm{O}_{3}$ & $\mathrm{NFX}$ \\
1 & 276 & 275 & $\mathrm{C}_{15} \mathrm{H}_{18} \mathrm{FN}_{3} \mathrm{O}$ & $\mathrm{Da}(1)$ \\
2 & 236 & 235 & $\mathrm{C}_{13} \mathrm{H}_{18} \mathrm{FN}_{3}$ & $\mathrm{Da}(2)$ \\
3 & 352 & 351 & $\mathrm{C}_{16} \mathrm{H}_{18} \mathrm{FN}_{3} \mathrm{O}_{5}$ & $\mathrm{Da}(3)$ \\
4 & 320 & 319 & $\mathrm{C}_{16} \mathrm{H}_{18} \mathrm{FN}_{3} \mathrm{O}_{3}$ & $\mathrm{Da}(4)$ \\
5 & 196 & 195 & $\mathrm{C}_{10} \mathrm{H}_{14} \mathrm{FN}_{3}$ & $\mathrm{Da}(5)$ \\
6 & 212 & 211 & $\mathrm{C}_{10} \mathrm{H}_{15} \mathrm{FN}_{3} \mathrm{O}$ & $\mathrm{Da}(6)$ \\
7 & 184 & 183 & $\mathrm{C}_{8} \mathrm{H}_{10} \mathrm{FN}_{3} \mathrm{O}$ & $\mathrm{Da}(7)$ \\
8 & 168 & 167 & $\mathrm{C}_{8} \mathrm{H}_{10} \mathrm{FN}_{3}$ & $\mathrm{Da}(8)$ \\
9 & 251 & 250 & $\mathrm{C}_{12} \mathrm{H}_{11} \mathrm{FN}_{2} \mathrm{O}_{3}$ & $\mathrm{Da}(9)$ \\
10 & 318 & 317 & $\mathrm{C}_{16} \mathrm{H}_{19} \mathrm{~N}_{3} \mathrm{O}_{4}$ & $\mathrm{Da}(10)$ \\
\hline
\end{tabular}




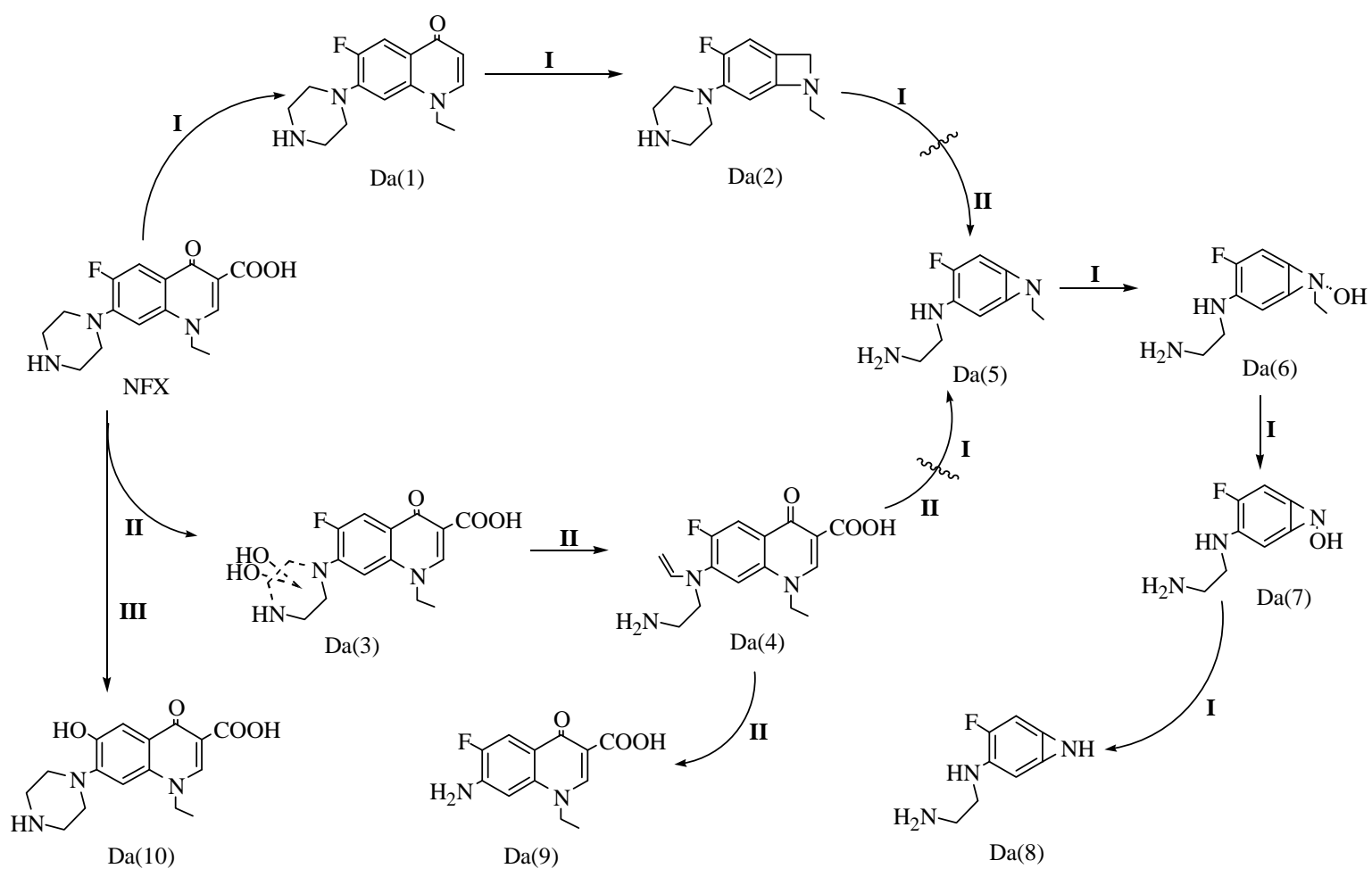

Scheme 1. The proposed catalytic degradation pathways for NFX.

lidixic ring, resulting in ring-opening, and the opened ring is then oxidized. (2) Pathway II: oxidation at the piperazine ring. Hydroxyl radicals attack and substitute the piperazine ring. Ring-opening of the piperazine ring occurs as a result of oxidation by hydroxyl radicals, and then the opened piperazine ring is further oxidized, leading to cleavage of $\mathrm{C}_{4} \mathrm{H}_{7} \mathrm{~N}$ (No. 9, Table 2). (3) Pathway III: oxidation at the benzene ring. As a result of strong oxidation by hydroxyl radicals, the F atom connected to the benzene ring is substituted by a hydroxyl, generating intermediates of mass 318 units. The structures of some of the products (No. 5, Table 2) showed that both the piperazine ring and the nalidixic ring were oxidized.

\subsection{Stability of catalytic activity of om- $\mathrm{MnO} \mathrm{O}_{x}$}

The stability of the catalytic activity of om- $\mathrm{MnO}_{x}$ was tested by performing five runs at $\mathrm{pH} 3.0,7.1$, and 8.7, respectively. Withdrawn samples were filtered using a $0.22-\mu \mathrm{m}$ syringe filter, and the NFX degradation efficiency and the concentration of $\mathrm{Mn}$ ions in aqueous solutions were monitored. No detectable leaching of $\mathrm{Mn}$ ions was found under the $\mathrm{pH}$ conditions used $\left(3.0,7.1\right.$, and 8.7), and the catalytic activity of om- $\mathrm{MnO}_{x}$ was unchanged after the fifth run.

\section{Conclusions}

Ordered mesoporous manganese oxide was shown to have significant catalytic activity in degradation of NFX using hydrogen peroxide. Promotion of hydroxyl radical generation was proposed as the reaction mechanism. Fenton's reagent, a well-known homogeneous catalytic hydrogen peroxide system, is effective at $\mathrm{pH}$ 2.0-5.0. However, catalysis by ordered mesoporous $\mathrm{MnO}_{x}$ proceeds in the $\mathrm{pH}$ range 3.0-8.7, and thus is promising for practical applications.

\section{References}

[1] Thiele-Bruhn S. J Plant Nutr Soil Sci, 2003, 166: 145

[2] Hooper D C, Wolfson J S. Quinolone Antibacterial Agents. 2nd Ed. Washington: American Society for Microbiology, 1993. 384

[3] Alexy R, Kümpel T, Kümmerer K. Chemosphere, 2006, 57: 505

[4] Zhang L L, Nie Y L, Hu C, Hu X X. J Hazard Mater, 2011, 190: 780

[5] Han Y F, Chen F X, Ramesh K, Zhong Z Y, Widjaja E, Chen L W. Appl Catal B, 2007, 76: 227

[6] Watts R J, Saras Ja, Loge F J, Teel A L. J Environ Eng, 2005, 131: 158

[7] Yang L, Hu C, Nie Y L, Qu J H. Environ Sci Technol, 2009, 43: 2525

[8] Sui M H, Liu J, Sheng L. Appl Catal B, 2011, 106: 195

[9] Taguchi A, Schüth F. Microporous Mesoporous Mater, 2005, 77: 1

[10] Li L X, Hua P, Tian X K, Yang C, Pi Z B. Electrochim Acta, 2010, 55: 1682

[11] Zhao D, Feng J, Huo Q, Melosh N, Fredrickson G H, Chmelka B F, Stucky G D. Science, 1998, 279: 548

[12] Tian Z R, Tong W, Wang J Y, Duan N G, Krishnan V V, Suib S L. Science, 1997, 276: 926

[13] Ernst M, Lurot F, Schrotter J C. Appl Catal B, 2004, 47: 15

[14] Sui M H, Sheng L, Lu K X, Tian F. Appl Catal B, 2010, 96: 94

[15] Karl W, Schneider J, Wetzstern H G. Appl Microbiol Biotechnol, 2006, 71: 101

[16] Eisenberg G M. Ind Eng Chem Anal, 1943, 15: 327

[17] Dodd M C, Kohler H P E, Von Gunten U. Environ Sci Technol, 2009, 43: 2498

[18] Paul T, Dodd M C, Strathmann T J. Water Res, 2010, 44: 3121 


\section{Graphical Abstract}

Chin. J. Catal., 2013, 34: 536-541 doi: 10.1016/S1872-2067(11)60492-0

\section{Ordered mesoporous manganese oxide as catalyst for hydrogen} peroxide oxidation of norfloxacin in water

SUI Minghao*, SHE Lei, SHENG Li, WEI Jinjie, ZHANG Lingdian, HUANG Shuhang

Tongji University

Compared with $\mathrm{MnO}_{x}$ without pores, ordered mesoporous $\mathrm{MnO}_{x}$ exhibited marked catalytic activity towards $\mathrm{H}_{2} \mathrm{O}_{2}$ for degradation of norfloxacin in aqueous solutions.
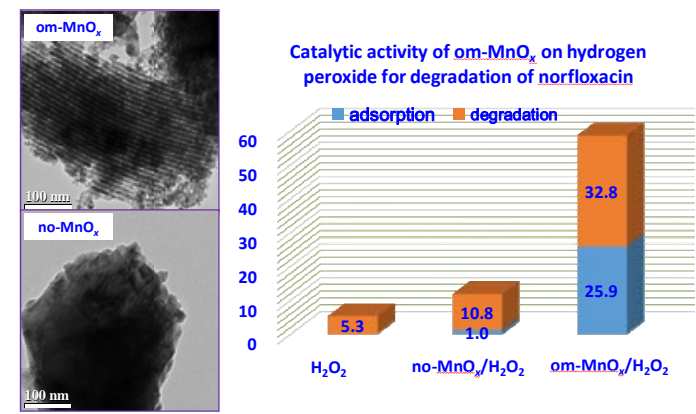

[19] Meynen V, Cool P, Vansant E F. Microporous Mesoporous Mater, 2009, 125: 170

[20] Zhu S M, Zhou Z Y, Zhang D, Wang H H. Microporous Mesoporous Mater, 2006, 95: 257

[21] Buxton G V, Greenstock C L, Helman W P, Ross A B. J Phys Chem Ref

Data, 1988, 17: 513

[22] Ervens B, Gligorovski S, Herrmann H. Phys Chem Chem Phys, 2003, 5: 1811

[23] Witte B D, Dewulf J, Demeestere K, Vyvere V V D, Wispelaere P D, Langenhove H V. Environ Sci Technol, 2008, 42: 4889

\section{有序介孔锰氧化物催化过氧化氢降解水中诺氟沙星}

隋铭皓*, 余 䂞, 盛 力, 魏金杰, 张令滇, 黄书杭

同济大学环境科学与工程学院污染控制与资源化国家重点实验室，上海 200092

摘要: 采用硬模板法制备了有序介孔氧化锰, 并用过氧化氢氧化诺氟沙星的降解率及其抗菌活性变化评价了其催化活性. 研究发 现, 有序介孔锰氧化物表现出较高的催化活性; 低 $\mathrm{pH}$ 有利于提高其催化活性. 与单独过氧化氢氧化过程相比, 有序介孔锰氧化 物的存在明显减弱了诺氟沙星的抗菌活性. 叔丁醇对催化体系的抑制作用表明有序介孔锰氧化物促进了过氧化氢分解生成着基 自由基. 通过对诺氟沙星在催化过程中的分解产物鉴定, 提出了可能的分解途径.

关键词: 有序介孔; 锰氧化物; 过氧化氢; 氧化; 诺氟沙星

收稿日期: 2012-08-31. 接受日期: 2012-11-22. 出版日期: 2013-03-20.

*通讯联系人. 电话: (021)65982691; 传真: (021)65986313; 电子信箱: suiminghao.sui@gmail.com 基金来源：国家自然科学基金 (50708067，51078281，51278351); 百篇优秀博士论文项目 (2007B48); 国家科技重大专项 (2012ZX07408001); 中央高校基本科研业务费专项基金 (0400219192).

本文的英文电子版由Elsevier出版社在ScienceDirect上出版(http://www.sciencedirect.com/science/journal/18722067). 